\title{
DIAGNOSIS DAN TATALAKSANA BENIGN PROSTATIC HYPERPLASIA: SEBUAH STUDI LITERATUR
}

\author{
Harie Sagita Novendi \\ Fakultas Kedokteran, Universitas Mataram, Indonesia. \\ Email: harienovendi037@gmail.com
}

\begin{abstract}
Abstrak
Benign Prostatic Hyperplasia (BPH) merupakan suatu kondisi medis yang sering ditemukan pada pria dan angka kejadiannya dipengaruhi oleh faktor usia. Pada studi otopsi didapatkan prevalensi histologis BPH sebesar $8 \%$ pada dekade keempat kehidupan, 50\% pada dekade keenam kehidupan, dan $80 \%$ pada dekade kesembilan kehidupan. Penulisan artikel ini berfokus pada pembahasan diagnosis dan tatalaksana BPH. Metode yang digunakan dalam penulisan artikel ini adalah studi literatur (literature review) yang relevan dari berbagai referensi meliputi jurnal ilmiah, panduan klinis terbaru dari IAUI, situs web, dan buku teks terbaru dan terpercaya mengenai topik Benign prostatic hyperplasia $(\mathrm{BPH})$. Berdasarkan penelusuran literatur, diagnosis BPH ditegakkan berdasarkan anamnesis, pemeriksaan fisik, dan pemeriksaan penunjang yang tepat. Pada anamnesis penting untuk menggali berbagai keluhan yang khas pada pasien BPH. Pada pemeriksaan fisik bisa dilakukan pemeriksaan status neurologis dan Colok dubur atau digital rectal examination, sedangkan pada pemeriksaan penunjang dapat dilakukan pemeriksaan yang bisa membantu memastikan diagnosis BPH, meliputi pemeriksaan urinalis, PSA, pencitraan atau radiologi, residu urine, dan uroflowmetry. Pilihan terapi atau tatalaksana pada pasien BPH terdiri dari terapi konservatif (watchful waiting), medikamentosa, dan pembedahan. BPH merupakan suatu kondisi medis yang sering ditemukan pada pria dan angka kejadiannya dipengaruhi oleh faktor usia. Penyakit ini bersifat progresif dan menyebabkan penurunan kualitas hidup yang signifikan. Diagnosis BPH ditegakkan berdasarkan anamnesis, pemeriksaan fisik, dan pemeriksaan penunjang yang tepat. Pilihan terapi atau tatalaksana pada pasien BPH terdiri dari terapi konservatif (watchful waiting), medikamentosa, dan pembedahan.
\end{abstract}

Kata kunci: Prostat; Benign Prostatic Hyperplasia; Diagnosis; Tatalaksana

\section{Abstract}

Benign Prostatic Hyperplasia (BPH) is a medical condition that is often found in men and its incidence is influenced by age. In autopsy studies, the histologic prevalence of $\mathrm{BPH}$ was $8 \%$ in the fourth decade of life, $50 \%$ in the sixth decade of life, and $80 \%$ in the ninth decade of life. In addition, Benign Prostatic Hyperplasia (BPH) is a disease that is progressive and causes a decrease in the quality of life in men. Therefore, knowledge about the diagnosis and good management of BPH needs to be understood by every clinician. The writing of this article focuses on discussing the diagnosis and management of BPH. The method used in writing this article is literature review relevant sources from various references include scientific journals, the latest clinical guides from IAUI, websites, and the latest and most trusted textbooks on the topic of Benign prostatic 
hyperplasia (BPH). Based on the literature search, the diagnosis of BPH was established based on anamnesis, physical examination, and appropriate supporting examinations. In the history it is important to explore the various complaints that are typical of BPH patients. BPH is a medical condition that is often found in men and its incidence is influenced by age. This disease is progressive and causes a significant reduction in quality of life. The diagnosis of $\mathrm{BPH}$ is based on anamnesis, physical examination, and appropriate investigations. Treatment options or management in BPH patients consist of conservative therapy (watchful waiting), medication, and surgery.

Keywords: Prostate; Benign Prostatic Hyperplasia; Diagnosis; Management

Diserahkan: 07-01-2022Ｄiterima: 25-01-2022Ｄiterbitkan: 20-02-2022

\section{Pendahuluan}

Benign Prostatic Hyperplasia (BPH) secara histopatologis didefinisikan sebagai suatu kondisi peningkatan jumlah sel stroma dan sel epitel dari kelenjar prostat (Roehrborn, 2008). BPH merupakan suatu kondisi medis yang sering ditemukan pada pria dan angka kejadiannya dipengaruhi oleh faktor usia (Altaf, Hyder Arain, Devrajani, \& Baloch, 2016). Hal ini dibuktikan berdasarkan studi otopsi didapatkan prevalensi histologis BPH sebesar 8\% pada dekade keempat kehidupan, 50\% pada dekade keenam kehidupan, dan 80\% pada dekade kesembilan kehidupan (Lim, 2017; Patel \& Parsons, 2014; Praveen, 2013). Kasus BPH di AS menunjukkan angka 70\% terjadi pada pria berusia 60-69 tahun dan 80\% berusia lebih dari 70 tahun (Parsons, 2010). Prevalensi BPH di Indonesia secara pasti belum pernah diteliti, tetapi berdasarkan data yang didapatkan di Rumah Sakit Cipto Mangunkusumo (RSCM) sejak tahun 1994-2013 jumlah kasus yang ditemukan sebesar 3.804 kasus dengan rata-rata usia pasien 66,61 tahun (Mochtar et al., 2015).

Benign Prostatic Hyperplasia (BPH) merupakan penyakit yang bersifat progresif dan menyebabkan penurunan kualitas hidup pada pria (Lu \& Chen, 2014; Yucel, Aras, Yalcinkaya, Kemal Hatipoglu, \& Aras, 2013). Proliferasi sel pada BPH menyebabkan peningkatan volume prostat dan peningkatan tonus otot polos stroma yang dapat menyebabkan kompresi fisik pada uretra sehingga mengakibatkan obstruksi pada saluran keluar kandung kemih. Obstruksi ini pada gilirannya, dapat muncul secara klinis sebagai gejala saluran kemih bagian bawah (LUTS), infeksi saluran kemih, retensi urin akut, hematuria gagal ginjal, dan batu kandung kemih (Patel \& Parsons, 2014).

Mengingat tingginya angka kejadian BPH pada populasi dan pengaruh yang ditimbulkan pada kualitas hidup pria, maka pengetahuan mengenai diagnosis dan tatalaksana BPH yang baik perlu dipahami oleh setiap klinisi. Penulisan artikel ini berfokus pada pembahasan diagnosis dan tatalaksana BPH. 


\section{Metode Penelitian}

Metode yang digunakan dalam penulisan artikel ini adalah studi literatur (literature review) yang relevan dari berbagai referensi meliputi jurnal ilmiah, panduan klinis terbaru dari IAUI, situs web, dan buku teks terbaru dan terpercaya mengenai topik Benign prostatic hyperplasia (BPH). Pencarian sumber dilakukan di portal online publikasi jurnal sebanyak 23 sumber yang berasal dari Pubmed (https://pubmed.ncbi.nlm.nih.gov/), Google Scholar (scholar.google.com), Nation Center for Biotechnology Information/ NCBI (ncbi.nlm.nih.gov), dan ResearchGate (https://www.researchgate.net/) dengan kata kunci Benign Prostatic Hyperplasia, treatment of $\mathrm{BPH}$, tatalaksana $\mathrm{BPH}$, dan diagnosis $\mathrm{BPH}$.

\section{Hasil dan Pembahasan}

Benign prostatic hyperplasia $(\mathrm{BPH})$ adalah tumor jinak yang paling umum pada pria, dan kejadiannya berkaitan dengan usia (Walsh \& Smith, 2013). BPH secara histopatologis ditandai dengan peningkatan jumlah sel epitel dan stroma (hiperplasia) di daerah peri-uretra prostat. Peningkatan jumlah sel prostat dapat menunjukkan adanya proliferasi sel epitel dan stroma, gangguan kematian sel terprogram, atau kombinasi keduanya (Reynard, Brewster, \& Biers, 2013). Secara klinis BPH merupakan prostat adenoma yang menyebabkan berbagai derajat obstruksi saluran keluar kandung kemih dengan atau tanpa gejala (Vasanwala, Wong, Ho, \& Foo, 2017).

\section{A. Perjalanan Alamiah Penyakit}

Secara umum riwayat alamiah BPH terdiri dari dua fase yaitu fase patologis dan fase klinis. Fase patologis yaitu fase BPH belum bergejala. Pada fase patologis terjadi perkembangan hiperplasia di zona transisional prostat namun belum ada keluhan dari pasien. Fase kedua yaitu fase klinis, yaitu fase timbulnya gejala klinis pada BPH berupa LUTS (Lower Urinary Tract Symptom) (Lawrentschuk \& Perera, 2016). Peningkatan ukuran prostat mengakibatkan terjadinya obstruksi pada leher buli-buli dan uretra prostatika atau disebut sebagai BOO (Bladder Outlet Obstruction). Kondisi obstruksi ini dapat menghambat aliran urine, sehingga mengakibatkan tekanan intravesika meningkat. Peningkatan tekanan intravesika mengakibatkan buli-buli harus berkontraksi lebih kuat guna melawan tahanan sehingga urine dapat keluar. Kontraksi yang terus menerus ini menyebakan perubahan anatomi buli-buli berupa hipertrofi otot detrusor, trabekulasi, terbentuknya selula, sakula, dan divertikel buli-buli. Perubahan struktur pada buli-buli tersebut, oleh pasien dirasakan sebagai keluhan pada saluran kemih sebelah bawah atau lower urinary tract symptom (LUTS) (Purnomo, 2012; Tanto et al., 2014).

\section{B. Manifestasi Klinis}

Keluhan yang dirasakan oleh pasien BPH seringkali berupa lower urinary tract symptoms (LUTS), yang terdiri atas gejala obstruksi (voiding symptoms), gejala iritasi (storage symptoms), dan gejala pasca berkemih. Gejala obstruksi meliputi pancaran kemih lemah dan terputus (intermitensi), merasa tidak puas sehabis berkemih, saat miksi pasien harus menunggu sebelum urine keluar (hesitancy), dan harus mengedan saat mulai miksi. Gejala iritasi meliputi frekuensi berkemih meningkat, urgensi (rasa tidak dapat 
menahan lagi saat ingin miksi), nokturia (terbangun saat malam hari untuk miksi), dan inkontinensia (urine keluar di luar kehendak). Gejala pasca berkemih berupa urine menetes (dribbling), hingga gejala yang paling berat adalah retensi urine (Mochtar et al., 2015; Tanto et al., 2014).

\section{Diagnosis}

Penegakan diagnosis BPH dilakukan melalui anamnesis, pemeriksaan fisik, dan pemeriksaan penunjang.

1. Anamnesis

Anamnesis merupakan pemeriksaan awal yang sangat penting dan harus dilakukan secara cermat guna mendapatkan data tentang riwayat penyakit yang diderita pasien. Anamnesis pada pasien BPH meliputi:

a. Keluhan utama yang dirasakan pasien dan berapa lama keluhan tersebut telah mengganggu

b. Riwayat penyakit lain dan penyakit pada saluran urogenital, seperti infeksi, kencing berdarah (hematuria), pernah mengalami cedera, kencing batu, atau pembedahan pada saluran kemih

c. Riwayat konsumsi obat yang dapat menimbulkan keluhan berkemih

d. Riwayat kesehatan secara umum dan keadaan fungsi seksual

e. Menilai dan memantau keadaan pasien BPH dengan menggunakan sistem penskoran yang digunakan secara luas yaitu International Prostate Symptom Score (IPSS). IPSS telah dikembangkan oleh American Urological Association (AUA) dan distandarisasi oleh World Health Organization (WHO).

f. Melakukan pencatatan harian berkemih, dengan mencatat kapan dan berapa jumlah asupan cairan yang dikonsumsi serta kapan dan berapa jumlah urine yang dikemihkan. Pencatatan ini sangat berguna pada pasien yang mengeluh nokturia sebagai keluhan utamanya (Mochtar et al., 2015).

2. Pemeriksaan Fisik

a. Status neurologis

Pemeriksaan fisik ginjal pada kasus BPH bertujuan untuk mengevaluasi adanya obstruksi atau tanda infeksi. Kemudian, pemeriksaan kandung kemih dilakukan untuk menilai isi kandung kemih dan ada tidaknya tanda infeksi. Pemeriksaan kandung kemih dilakukan dengan palpasi dan perkusi (Mochtar et al., 2015).

b. Colok dubur atau digital rectal examination (DRE)

Pemeriksaan colok dubur atau digital rectal examination (DRE) merupakan pemeriksaan fisik yang sangat penting pada pasien BPH. Pada pemeriksaan prostat aspek yang dinilai adalah bentuk, simetrisitas, kualitas, ada tidaknya nodul, dan konsistensi prostat. Dari pemeriksaan DRE bisa diidentifikasi apakah pasien mengalami BPH atau karsinoma prostat. Pada kondisi BPH akan didapatkan konsistensi prostat kenyal seperti meraba ujung hidung, lobus kanan dan kiri simetris dan tidak didapatkan nodul. Hal berbeda didapatkan pada kondisi 
karsinoma prostat, yaitu akan didapatkan konsistensi prostat keras, teraba nodul, dan kemungkinan di antara lobus prostat tidak simetris. Pada pemeriksaan DRE perlu juga untuk menilai tonus sfingter ani dan refleks bulbokavernosus untuk mengetahui ada tidaknya kelainan pada lengkung refleks di daerah sacral, sedangkan untuk mengukur volume prostat dengan DRE cenderung lebih kecil daripada ukuran yang sebenarnya (Mochtar et al., 2015; Purnomo, 2012; Tanguay et al., 2009).

3. Pemeriksaan Penunjang

a. Urinalisis

Pemeriksaan urinalisis diperlukan untuk menyingkirkan kemungkinan ISK, prostatitis, sistolitiasis, nefrolitiasis, kanker ginjal, dan kanker prostat sebagai penyebab gejala LUTS pada pasien. Pemeriksaan ini dapat menentukan adanya leukosituria dan hematuria (Mochtar et al., 2015; Skinder, Zacharia, Studin, \& Covino, 2016; Tanguay et al., 2009; Walsh \& Smith, 2013).

b. Prostate Specific Antigen (PSA)

Prostate Specific Antigen (PSA) merupakan antigen yang disintesis oleh sel epitel prostat. PSA bersifat spesifik organ tetapi tidak spesifik kanker. Pemeriksaan ini dilakukan untuk menilai perjalanan penyakit BPH. Kadar PSA yang tinggi dapat mengindikasikan laju pertumbuhan volume prostat yang lebih cepat, keluhan akibat BPH lebih berat, dan lebih mudah terjadi retensi urine akut. Rentang kadar normal PSA adalah sebagai berikut.

Tabel 1. Kadar Normal Prostate Specific Antigen (PSA) (Tanto et al., 2014)

\begin{tabular}{cc}
\hline Rentang Usia & Nilai Normal PSA \\
\hline $40-49$ tahun & $0-2,5 \mathrm{ng} / \mathrm{mL}$ \\
$50-59$ tahun & $0-3,5 \mathrm{ng} / \mathrm{mL}$ \\
$60-69$ tahun & $0-4,5 \mathrm{ng} / \mathrm{mL}$ \\
$70-79$ tahun & $0-6,5 \mathrm{ng} / \mathrm{mL}$ \\
\hline
\end{tabular}

Kadar PSA >4 ng/ml menunjukkan indikasi tindakan biopsi prostat dengan sebelumnya melakukan diskusi untuk mendapatkan persetujuan pasien. Pemeriksaan kadar PSA juga merupakan pemeriksaan yang sangat baik untuk menunjang pemeriksaan colok dubur untuk mendeteksi adanya karsinoma prostat (Mochtar et al., 2015; Tanto et al., 2014).

c. Pencitraan atau Radiologi

Pencitraan prostat merupakan pemeriksaan rutin yang bertujuan untuk menilai bentuk dan ukuran prostat (Mochtar et al., 2015). Pemeriksaan ini dapat dilakukan dengan menggunakan Ultrasonography/USG transabdominal atau transrektal (Mochtar et al., 2015; Purnomo, 2012). Pengukuran volume prostat dilakukan dengan rumus ellipsoid yakni dengan mengalikan tinggi anteroposterior terbesar $(\mathrm{H})$, lebar transversal $(\mathrm{W})$, panjang cephalocaudal $(\mathrm{L})$ dan diameter dengan rumus (Park et al., 2000): 


$$
\text { Prostate Volume }=\left(\text { height } \times \text { length } \times \text { width } \times \frac{\pi}{6}\right)
$$

Menurut Romero et al. (2012) derajat pembesaran prostat diklasifikasikan menjadi beberapa Grade yaitu, Grade I (20-40g), Grade II (40-60g), Grade III (60-80g), dan Grade IV ( $\geq 80 \mathrm{~g})$.
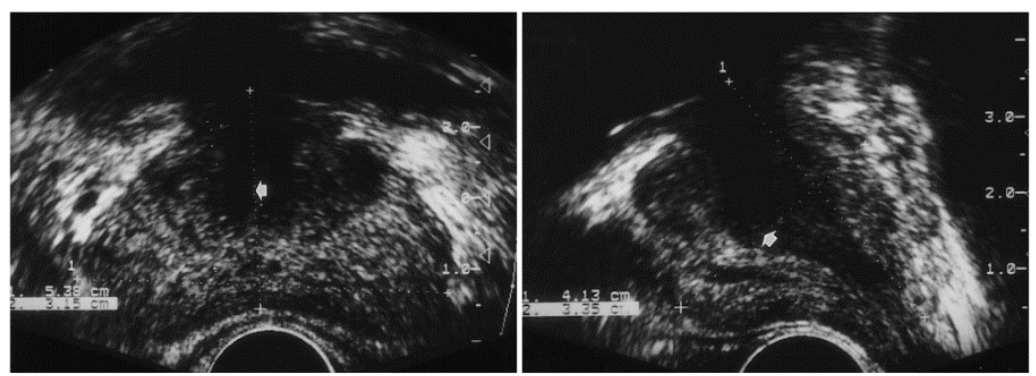

Gambar 1. TRUS (Transrectal ultrasonography) (Park et al., 2000)

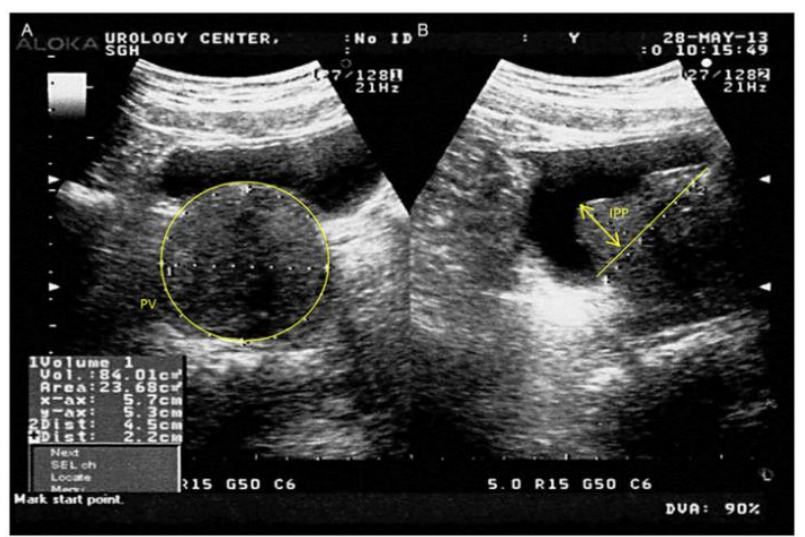

Gambar 2. TAUS (Transabdominal ultrasonography) (Foo, 2017)

d. Residu urine

Residu urine atau post voiding residual urine (PVR) merupakan ukuran seberapa banyak urin yang tersisa di kandung kemih setelah pasien berkemih (Magheli, 2014). Jumlah rata-rata residu urine pada pria normal adalah $12 \mathrm{~mL}$ (Mochtar et al., 2015). Pengukuran residu urine dapat dilakukan dengan metode katerisasi dan USG atau bladder scan. Metode katerisasi saat ini banyak ditinggalkan karena menimbulkan nyeri, cedera uretra, dan infeksi, sehingga saat ini pengukuran lebih sering menggunakan USG atau bladder scan setelah miksi (Purnomo, 2012).

e. Uroflowmetry (Pancaran Urine)

Uroflowmetry merupakan pemeriksaan pancaran urine selama proses berkemih dengan tujuan untuk mendeteksi gejala obstruksi saluran kemih bagian bawah (Mochtar et al., 2015). Dari pemeriksaan uroflowmetry bisa didapatkan beberapa informasi seperti lama proses miksi, laju pancaran, rerata pancaran, 
pancaran maksimum, waktu yang dibutuhkan untuk mencapai pancaran maksimum, dan volume urine yang dikemihkan (Purnomo, 2012).
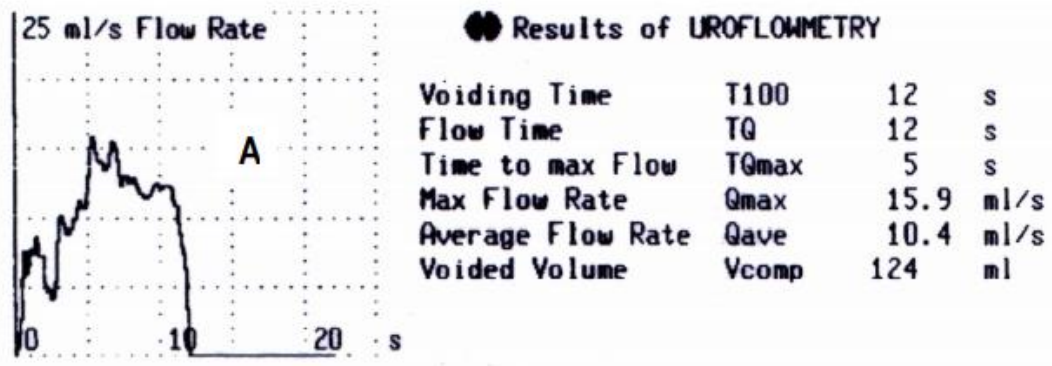

Gambar 3. Hasil uroflowmetry normal (Purnomo, 2012)

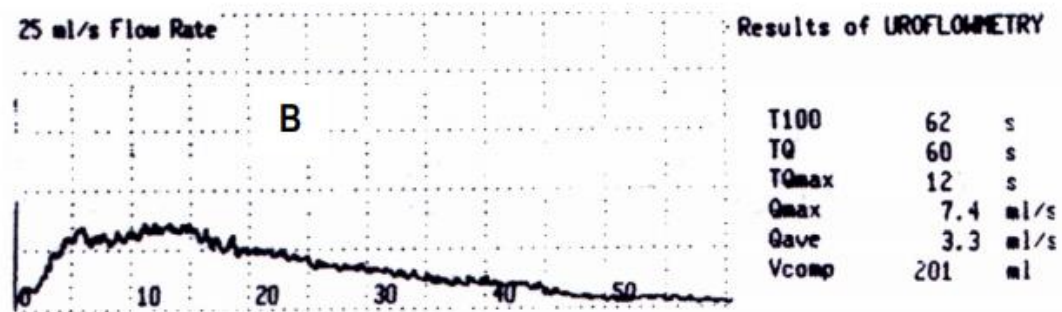

Gambar 4. Hasil uroflowmetry pada pasien BPH/LUTS (Purnomo, 2012)

\section{Tatalaksana}

Tujuan terapi pada pasien BPH adalah untuk memperbaiki keluhan berkemih, meningkatkan kualitas hidup, mengurangi obstruksi infravesika, mengurangi volume residu urine setelah miksi, mengembalikan fungsi ginjal jika terjadi gagal ginjal, dan mencegah progresifitas penyakit (Purnomo, 2012). Tatalaksana pada pasien BPH terdiri dari terapi konservatif (watchful waiting), medikamentosa, dan pembedahan. (Mochtar et al., 2015).

1. Terapi konservatif

Watchful waiting merupakan salah satu bentuk terapi konservatif pada pasien BPH yaitu pasien tidak mendapatkan terapi apapun tetapi perkembangan penyakitnya tetap diawasi oleh dokter (Mochtar et al., 2015; Tanguay et al., 2009). Terapi ini ditujukan untuk pasien BPH dengan nilai IPSS kurang dari 8, yaitu gejala ringan dan tidak mengganggu aktivitas sehari-hari (Skinder et al., 2016). Pasien dengan terapi watchful waiting harus diberikan penjelasan tentang kondisinya dan diminta untuk menghindari hal yang dapat memperburuk keluhannya, misalnya jangan mengonsumsi kopi atau alkohol setelah makan, jangan menahan kencing terlalu lama, mengurangi asupan cairan sebelum tidur, dan menghindari beberapa obat seperti diuretik, dekongestan, antihistamin, serta antidepresan. Setelah itu pasien diminta melakukan kunjungan berkala untuk memeriksakan kondisinya ke dokter. Apabila keluhan berkemih bertambah buruk maka perlu dipertimbangkan untuk melakukan terapi yang lain (Nickel et al., 2010; Purnomo, 2012). 


\section{Terapi medikamentosa}

Terapi medikamentosa bertujuan untuk mengurangi resistensi otot polos prostat sebagai komponen dinamik penyebab obstruksi infravesika dengan obatobatan penghambat adrenergik alfa $\left(\alpha_{1}\right.$ blocker $)$ dan mengurangi volume prostat sebagai komponen statik dengan cara menurunkan kadar hormon testosteron atau dihidrotestosteron (DHT) melalui 5 $\alpha$-reduktase inhibitor (Purnomo, 2012).

a. al blocker

Mekanisme kerja dari al blocker adalah dengan menghambat alfa1adrenoseptor yang dimediasi oleh stimulus simpatis sehingga mengakibatkan relaksasi otot polos di prostat dan leher kandung kemih (Tanguay et al., 2009). Obat $\alpha 1$ blocker merupakan pilihan terapi lini pertama yang sangat baik untuk pria dengan LUTS akibat BPH (Nickel et al., 2010). Obat ini mampu mengurangi LUTS hingga 30-45\% atau dengan penurunan 4-6 skor IPSS, tetapi tidak mengurangi volume prostat maupun risiko retensi urine dalam jangka panjang (Mochtar et al., 2015). Beberapa obat $\alpha$ l-blocker yang tersedia saat ini adalah alfuzosin, doxazosin, silodosin, tamsulosin, dan terazosin (Gravas et al., 2016).

b. 5 $\alpha$-reduktase inhibitor

$5 \alpha$-reduktase inhibitor merupakan pilihan obat lini pertama selain $\alpha 1$ blocker. Mekanisme kerja obat ini adalah dengan menghambat konversi

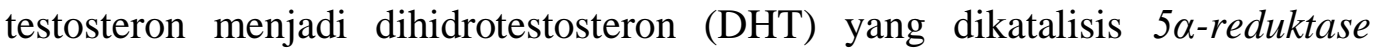
didalam sel-sel prostat, sehingga dapat menghambat hiperplasia prostat, mengurangi ukuran prostat, dan memperlambat progresivitas penyakit (Purnomo, 2012; Skinder et al., 2016). Penggunaan obat ini selama 6-12 bulan dapat menyebabkan pengurangan ukuran prostat sekitar 18-28\% dan penurunan kadar

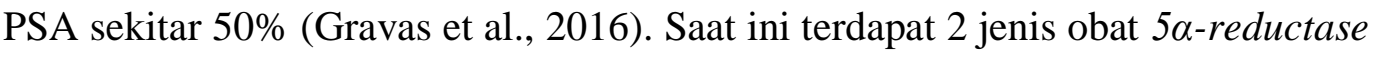
inhibitor yang digunakan untuk mengobati $\mathrm{BPH}$, yaitu finasteride dan dutasteride. Finasteride bekerja dengan menghambat $5 \alpha$-reduktase tipe 2, sedangkan dutasteride menghambat $5 \alpha$-reduktase tipe 1 dan 2 dengan potensi serupa (dual inhibitor) (Gravas et al., 2016; Purnomo, 2012).

c. Terapi kombinasi $\alpha 1$-blocker $+5 \alpha$-reductase inhibitor

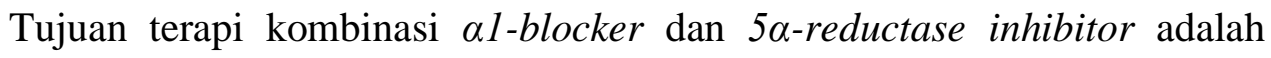
untuk mendapatkan efek sinergis dengan menggabungkan manfaat yang berbeda dari kedua golongan obat tersebut, sehingga meningkatkan efektivitas dalam memperbaiki gejala dan mencegah progresifitas penyakit. Data yang ada menunjukkan terapi kombinasi memberikan hasil yang lebih baik dibandingkan monoterapi untuk mencegah terjadinya retensi urine akut dan kemungkinan diperlukan terapi bedah, namun terapi kombinasi juga dapat meningkatkan risiko terjadinya efek samping (Mochtar et al., 2015). Terapi kombinasi direkomendasikan bagi pasien dengan rencana pengobatan jangka panjang $(>1$ tahun) dan pasien dengan keluhan LUTS sedang hingga berat dan mempunyai risiko progresi (Gravas et al., 2016).

3. Terapi pembedahan 
Pembedahan merupakan pilihan terapi yang dapat memperbaiki klinis pasien BPH secara objektif, tetapi dapat disertai berbagai penyulit pada saat atau setelah tindakan. Terapi pembedahan dilakukan pada pasien BPH berdasarkan beberapa indikasi seperti retensi urin akut, infeksi saluran kemih berulang, hematuria makroskopis, gagal ginjal, divertikulum buli yang besar, batu buli, gagal Trial Without Catheter (TwoC), penurunan fungsi ginjal, serta perubahan patologis lain pada kandung kemih dan saluran kemih bagian atas. Indikasi relatif lain untuk terapi pembedahan adalah keluhan pasien sedang hingga berat, tidak ada perbaikan dengan terapi nonbedah, dan pasien menolak medikamentosa (Mochtar et al., 2015; Tanto et al., 2014).

Terapi pembedahan yang dapat dilakukan pada pasien yang mengalami BPH secara umum dibagi menjadi invasif minimal dan operasi terbuka. Invasif minimal mencakup Transurethral Resection of the Prostate (TURP), Laser Prostatektomi, Transurethral Incision of the Prostate (TUIP), Transurethral Microwave Thermotherapy (TUMT), Transurethral Needle Ablation (TUNA), dan High Intensity Focused Ultrasound (HIFU). Operasi terbuka atau prostatektomi terbuka merupakan tindakan yang dianjurkan untuk prostat dengan volume lebih dari >80 $\mathrm{ml}$ dan dapat dilakukan melalui transvesikal atau retropubik. Tindakan ini merupakan cara operasi yang paling invasif dengan morbiditas lebih besar (Mochtar et al., 2015).

\section{Kesimpulan}

BPH merupakan suatu kondisi medis yang sering ditemukan pada pria dan angka kejadiannya dipengaruhi oleh faktor usia. Penyakit ini bersifat progresif dan menyebabkan penurunan kualitas hidup yang signifikan. Hal ini dikarenakan proliferasi sel pada BPH menyebabkan peningkatan volume prostat dan peningkatan tonus otot polos stroma yang dapat berakibat pada kompresi fisik uretra sehingga mengakibatkan obstruksi pada saluran keluar kandung kemih. Obstruksi ini pada gilirannya, dapat muncul secara klinis sebagai gejala saluran kemih bagian bawah (LUTS), infeksi saluran kemih, retensi urin akut, hematuria gagal ginjal, dan batu kandung kemih. Berdasarkan penelusuran literatur, diagnosis BPH ditegakkan berdasarkan anamnesis, pemeriksaan fisik, dan pemeriksaan penunjang yang tepat. Pada anamnesis penting untuk menggali berbagai keluhan yang khas pada pasien BPH. Pada pemeriksaan fisik bisa dilakukan pemeriksaan status neurologis dan Colok dubur atau digital rectal examination, sedangkan pada pemeriksaan penunjang dapat dilakukan pemeriksaan yang bisa membantu memastikan diagnosis BPH, meliputi pemeriksaan urinalis, PSA, pencitraan atau radiologi, residu urine, dan uroflowmetry. Pilihan terapi atau tatalaksana pada pasien BPH terdiri dari terapi konservatif (watchful waiting), medikamentosa, dan pembedahan. Terapi-terapi pada pasien BPH ini bertujuan untuk memperbaiki keluhan berkemih, meningkatkan kualitas hidup, mengurangi obstruksi infravesika, mengurangi volume residu urine setelah miksi, mengembalikan fungsi ginjal jika terjadi gagal ginjal, dan mencegah progresifitas penyakit. 


\section{BIBLIOGRAFI}

Altaf, Javed, Hyder Arain, Adeel, Devrajani, Bikha Ram, \& Baloch, Saira. (2016). Serum Electrolyte Disturbances in Benign Prostate Hyperplasia after Transurethral Resection of the Prostate. Journal of Nephrology \& Therapeutics, 06(01), 8-11. Google Scholar

Foo, Keong Tatt. (2017). Pathophysiology of clinical benign prostatic hyperplasia. Asian Journal of Urology, 4(3), 152-157. Google Scholar

Gravas, S., Bach, T., Bachmann, A., Drake, M., Gacci, M., Gratzke, C., Madersbacher, S., Mamoulakis, C., Tikkinen, K. A. O., Karavitakis, Guidelines Associates M., Malde, S., Sakkalis, V., \& Umbach, R. (2016). EAU Guidelines on Management of Non-Neurogenic Male Lower Urinary Tract Symptoms (LUTS) Benign Prostatic Obstruction ( BPO ). European Association of Urology 2016, 1-62. Google Scholar

Lawrentschuk, Nathan, \& Perera, Marlon. (2016). Benign Prostate Disorders (KR Feingold, B. Anawalt, A. Boyce, \& Et Al., eds.). Google Scholar

Lim, Kok Bin. (2017). Epidemiology of clinical benign prostatic hyperplasia. Asian Journal of Urology, 4(3), 148-151. https://doi.org/10.1016/j.ajur.2017.06.004 Google Scholar

Lu, Shing hwa, \& Chen, Chih shou. (2014). Natural history and epidemiology of benign prostatic hyperplasia. Formosan Journal of Surgery, 47(6), 207-210. Google Scholar

Magheli, Ahmed. (2014). Male infertility. In: Handbook of Urology (1st ed.; J. Kellogg Parsons, John B. Eifler, \& Misop Han, eds.). New Jersey: New Jersey: Wiley Blackwell. Google Scholar

Mochtar, Chaidir A., Umbas, Rainy, Soebadi, Doddy M., Rasyid, Nur, Noegroho, Bambang S., Poernomo, Basuki Bambang, Tjahjodjati, Danarto, H. R., Wijanarko, Suharto, Warli, Syah Mirsa, \& Hamid, Agus Rizal A. H. (2015). Panduan Penatalaksanaan Klinis Pembesaran Prostat Jinak ( Benign Prostatic Hyperplasia / BPH ) (2nd ed.). Jakarta: Jakarta: Ikatan Ahli Urologi Indonesia. Google Scholar

Nickel, J. Curtis, Méndez-probst, Carlos E., Whelan, Thomas F., Paterson, Ryan F., Razvi, Hassan, Council, Canadian Prostate Health, \& Committee, CUA Guidelines. (2010). 2010 Update: Guidelines for the management of benign prostatic hyperplasia. Canadian Urological Association Journal, 4(5), 310-316. Google Scholar

Park, Sung Bin, Kim, Jae Kyun, Choi, Sung Hoon, Noh, Han Na, Ji, Eun Kyung, \& Cho, Kyoung Sik. (2000). Prostate Volume Measurement by TRUS Using Heights Obtained by Transaxial and Midsagittal Scanning: Comparison with Specimen Volume Following Radical Prostatectomy. Korean Journal of Radiology, 1(2), 110 113. Google Scholar

Parsons, J. Kellogg. (2010). Benign Prostatic Hyperplasia and Male Lower Urinary Tract Symptoms : Epidemiology and Risk Factors. Current Bladder Dysfunction Reports, 5, 212-218. Google Scholar

Patel, Nishant D., \& Parsons, J. Kellogg. (2014). Epidemiology and etiology of benign prostatic hyperplasia and bladder outlet obstruction. Indian Journal of Urology, 
Diagnosis dan Tatalaksana Benign Prostatic Hyperplasia (BPH): Sebuah Kajian Literatur

30(2), 170-176. Google Scholar

Praveen, R. (2013). Benign Prostatic Hyperplasia: Updated Review. International Research Journal of Pharmacy, 4(8), 45-51. Google Scholar

Purnomo, Basuki B. (2012). Dasar-dasar Urologi (3rd ed.). https://doi.org/10.1016/b978-343741510-4.50023-7 Google Scholar

Reynard, John, Brewster, Simon, \& Biers, Suzanne. (2013). Oxford Handbook of Urology (3rd ed.). United Kingdom: United Kingdom: Oxford University Press. Google Scholar

Roehrborn, C. G. (2008). Pathology of benign prostatic hyperplasia. International Journal of Impotence Research, 20, S11-S18. https://doi.org/10.1038/ijir.2008.55 Google Scholar

Romero, Frederico Ramalho, Romero, Antonio W., Filho, Thadeu Brenny, Kulysz, David, Jr, Fernando C. Oliveira, \& Filho, Renato Tambara. (2012). The prostate exam. Health Education Journal, 71(2), 239-250. Google Scholar

Skinder, Danielle, Zacharia, Ilana, Studin, Jillian, \& Covino, Jean. (2016). Benign prostatic hyperplasia: A clinical review. Journal of the American Academy of Physician Assistants, 29(8), 19-23. Google Scholar

Tanguay, Simon, Awde, Murray, Brock, Gerald, Casey, Richard, Kozak, Joseph, Lee, Jay, Nickel, J. Curtis, \& Saad, Fred. (2009). Diagnosis and management of benign prostatic hyperplasia in primary care. Canadian Urological Association Journal, 3(3), 92-100. Google Scholar

Tanto, Chris, Liwang, Frans, Hanifati, Sonia, \& Pradipta, Eka Adip. (2014). Kapita Selekta Kedokteran Jilid I (4th ed.). Jakarta: Jakarta: Media Aesculapius. Google Scholar

Vasanwala, Farhad Fakhrudin, Wong, Michael Yuet Chen, Ho, Henry Sun Sien, \& Foo, Keong Tatt. (2017). Benign prostatic hyperplasia and male lower urinary symptoms: A guide for family physicians. Asian Journal of Urology, 4(3), 181-184. Google Scholar

Walsh, Thomas J., \& Smith, James F. (2013). Male Infertility. In: Smith \& Tanagho 's General Urology (18th ed.; Jack W. McAninch \& Tom F. Lue, eds.). New York: New York: McGraw-Hill. Google Scholar

Yucel, Mehmet, Aras, Bekir, Yalcinkaya, Soner, Kemal Hatipoglu, Namik, \& Aras, Erol. (2013). Conventional monopolar transurethral resection of prostate in patients with large prostate ( $\geq 80$ grams). Central European Journal of Urology, 66(3), 303-308. Google Scholar

\section{First publication right:}

Jurnal Syntax Fusion: Jurnal Nasional Indonesia

This article is licensed under:

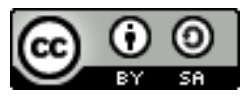

